\title{
Determinants of Indonesian professionals' soccer spectator loyalty
}

\author{
Fatchur Rohman $^{\mathrm{a}^{*}}$
}

\begin{abstract}
${ }^{a}$ Universitas Brawijaya, Indonesia C H R O N I C L E

Article history:

Received: May 30, 2020

Received in revised format:

May 302020

Accepted: July 6, 2020

Available online:

July 6, 2020

Keywords:

Experience quality

Club image

Satisfaction

Subjective well-being

Spectator loyalty

A B S T R A C T

This study aims to investigate the relationship among sport experiential quality, club image, spectator satisfaction, subjective well-being, and spectator loyalty in the context of the Indonesian professional soccer industry. In addition, this study determines the mediating role of club image, spectator satisfaction, and subjective well-being in the relationship between sport experiential quality and spectator loyalty. To answer the research objectives, this study employed an explanatory research approach. Self-administered questionnaire was distributed among 250 samples recruited from several professional soccer matches in East-Java Province during Indonesia Soccer League (ISL) 2019. Data were analyzed by Partial Least Squares (PLS) technique. The results indicate that sport experiential quality did not have any significant direct effect on spectator loyalty. However, spectator experiential quality significantly affected club image, spectator satisfaction, and subjective well-being. While spectator experiential quality did not have a direct effect on spectator loyalty, the results also show that club image, subjective well-being, and spectator satisfaction had significant positive effects on spectator loyalty. Apart from the direct effect, this study indicate that subjective well-being, club image, and spectator satisfaction mediated the effect of spectator experiential quality on spectator loyalty.
\end{abstract}

\section{Introduction}

In the domain of customer relationship paradigm, the idea of customer loyalty is considered substantial (Hapsari, Clemes, \& Dean, 2017), as having loyal customers would give more benefits for business organizations than attracting the new one. Like business organizations, a modern professional soccer team also needs to have loyal spectators as the spectators would be the source of team revenue. The loyal spectators contribute to the team revenue by purchasing ticket matches and team attributes such as t-shirts, scarves, and other memorabilia. Also, having loyal spectators will enhance the opportunities of a professional soccer team to have extra funding from sponsorship. Referring to the Stimulus-Organism-Response (S-O-R) Theory of consumer behaviour studies, this study predicted that an appropriate stimulus received by spectators would generate loyalty. Within the area of sports marketing, service quality has been recognized widely as the robust determinant of customer loyalty. Previous studies (Chun Ma \& Kaplanidou, 2019; Clemes, Brush, \& Collins, 2011) suggested that service quality perceived by the spectators has a significant positive effect on behavioural intention through emotional arousals such as satisfaction and perceived value. In the area of marketing, many studies have recognized the importance of service quality as a stimulus received by customers in affecting behavioural intention (Brady \& Cronin, 2001; Hapsari et al., 2017; Keshavarz \& Jamshidi, 2018; Su, Swanson, \& Chen, 2016). While service quality has been recognized widely as the determinant of behavioural intention, a gap still exists in the literature regarding the robustness of service quality in predicting customer loyalty. Scholars (Hussein, 2018b; Lemke, Clark, \& Wilson, 2011) argued that the notion of service quality is not enough to explain behavioural intention as it is only explaining the service performance at the attribute level. There is a need to find a more robust notion to 
replace the idea of service quality. In order to fill this research gap, this study developed the notion of spectator experiential quality rooted in Service-Dominant (S-D) Logic theory (Vargo \& Lusch, 2010). This theory suggested that experience is the result of interaction between customer and service provider. This interaction allows the customer to co-create the value requested. Hence, using the construct of spectator experiential quality will give a deeper meaning for sport marketing studies than the idea of service quality.

Apart from experience quality, previous studies have identified several constructs affecting behavioural intention such as customer satisfaction (Liat, Chuan, \& Shaheen, 2019), trust (Hapsari, Hussein, \& Handrito, 2020), brand image (Kandampully $\&$ Suhartanto, 2000), and subjective well-being (Majid \& Sadiq, 2017). While these variables have been recognized as the determinants of customer loyalty, lack of published studies have formed a comprehensive conceptual model integrating the notion of experience quality, satisfaction, image, subjective well-being in predicting spectator loyalty. The previous sport marketing studies were only focussed on the partial relationship among these constructs. For example, Chun Ma and Kaplanidou (2019) investigated the relationships among service quality, perceived value, and behavioural dimensions. Clemes et al. (2011) focussed on service quality, customer satisfaction, trust, fan ship, and behavioural intention. Hussein (2018) suggested that building a more comprehensive model will increase the predictive power of the model. Thus, this study will conceptualize a comprehensive model in predicting spectator loyalty by integrating the constructs of spectator experiential quality, spectator satisfaction, club image, subjective-well-being, and behavioural intention. Based on the background of the study, two research objectives are addressed in this study. First, this study aims to investigate the relationship among spectators' experiential quality, club image, spectator satisfaction, subjective well-being and loyalty in the area of the Indonesian professional soccer industry. The second objective is to investigate the mediating role of club image, spectator satisfaction and subjective well-being in the relationship between spectator experiential quality and loyalty. Upon the completion of this study, both theoretical and practical contributions are provided. As for theoretical contribution, this study provided a comprehensive conceptual model explaining the relationship among spectator experiential quality, club image, spectator satisfaction, subjective well-being, and spectator loyalty. In addition, this study showed the importance of spectator satisfaction, club image and subjective well-being in mediating the effect of spectator experiential quality on loyalty. From a practical standpoint, this study will give insight for professional soccer club managers to create spectator loyalty.

\section{Literature review}

\subsection{Spectator Experience Quality and Spectator Loyalty}

Stimulus-Organism-Response (S-O-R) Theory (Mehrabian \& Russel, 1974) proposed that a stimulus received by individuals would generate a response based on internal evaluation. It is explained that stimulus would affect emotional arousal, which lastly creates responses and has been discussed widely as a strong stimulus generating behavioural response (Ali, Kim, Li, \& Jeon, 2018; Rather, 2020; Wu, Cheng, \& Ai, 2018). In the domain of marketing studies, the idea of experience quality was derived from Service-Dominant (S-D) Logic theory. Hussein (2018) explained that experience is about the individual's response toward the direct and indirect meeting with service providers and experience, while quality is about the superior performance of experience. Hence, spectator experience quality (SEQ) is about superior performance as the results of direct and indirect interaction between spectators and the supported club. As a response from individual behaviour, previous studies found that experience quality has a significant positive effect on behavioural intention. For example, the study of Hussein, Hapsari, and Yulianti (2018) found that boutique hotel experience quality positively affects customer loyalty. Similar to this study, Wu, Wong, and Cheng (2014) suggested that food festival experience quality has a significant positive effect on visitor behavioural intention. These studies argued that the more positive an experience quality is perceived, the more loyal the customer will be. Apart from its important role in affecting loyalty, experience quality was found to have a significant positive effect on subjective well-being. The studies of Baloglu, Busser, and Cain (2019) in the area of the spa industry showed that experience quality played an important role in affecting individual subjective well-being. Similar to this study, Huang, Chen, and Gao (2019) contended that the subjective well-being of Taiwan Hotel Spa visitors is affected by their experience with the spa. As the robust determinant of customer loyalty, the idea of experience quality has been proven as the determinant of brand image. Hapsari, Clemes, and Dean (2017) suggested that the quality of service provided by airplane as part of customer experience quality significantly affects customer loyalty. Hussein et al. (2018) explained that boutique hotel experience quality has a significant positive effect on hotel image. The idea of customer satisfaction is about the gap between what is expected and perceived by the customers. Experience quality has been recognized to have a significant positive effect on customer satisfaction. The study of Chen and Chen (2010) contended that heritage tourist experience quality has a significant positive effect on tourist satisfaction. The significant effect of experience quality on satisfaction was also found by Jin, Lee, and Lee (2015) in the context of a water park.

Based on the previous studies, four hypotheses were proposed:

H1 : SEQ has a significant positive effect on spectator loyalty.

H2 : SEQ has a significant positive effect on subjective well-being.

H3 : SEQ has a significant positive effect on club image.

H4 : SEQ has a significant positive effect on spectator satisfaction. 


\subsection{Club Image}

The construct of club image was derived from the concept of corporate image. Andreassen and Lindestad (1998) suggested that image was developed in the consumer mind via communication and experience. In addition, it is suggested that image is an extrinsic cue for the potential or existing customers to purchase products. Hapsari et al. (2017) suggested that brand image is about the perception of customers toward a brand as reflected by a brand association held in the memory of customers. Accordingly, the club image refers to the spectators' perception of the club association to the spectators' perceived and held memory. From the marketing perspective, both brand and corporate image have been recognized to have an important role in shaping individual subjective well-being. Reflecting S-O-R Theory (Mehrabian \& Russell, 1974), a stimulus received by an individual will create emotional arousal. Thus, subjective well-being as an individual emotional feeling is the result of image as an external stimulus. This argument was also supported by the study of Majid and Sadiq (2017) found that mall image has a significant positive effect on visitor subjective well-being. Similar to its effect on subjective well-being (SWB), image was also suggested to be the determinant of customer loyalty. The study of Hussein (2018) showed the significant positive effect of restaurant image on customer loyalty. In accordance with this study, Shafiee and Es-Haghi (2017) suggested the effect of mall image on customer loyalty. In the area of sports marketing, Bauer, Stokburger-Sauer, and Exler (2008) revealed the essential role of professional club image in creating fan loyalty. As previous sections discussed the effect of experiential quality on image (Hapsari et al., 2017; Hussein et al., 2018) and it is suggested that club image plays an important role in affecting spectator loyalty, there is a possibility that club image will intervene the effect on spectator experiential quality on spectator loyalty. It means, apart from its direct effect on loyalty, spectator experiential quality will affect loyalty via club image. Based on the literature review, this study suggested:

H5 : Club Image has a significant positive effect on SWB.

H6 : Club Image has a significant positive effect on spectator loyalty.

H7 : Club image mediates the effect of Spectator Experiential Quality on spectator loyalty.

\subsection{Spectator Satisfaction}

The notion of customer satisfaction is about the gap between customers' expectation and their perception (Kotler \& Keller, 2012). If the perception received is better than the expectation, customers will be satisfied. Vice versa, if the expectation of customers is higher than their perception, customers will be dissatisfied. In the domain of marketing studies, customer satisfaction has been admitted as an important construct. Previous studies explained that satisfaction has a significant positive effect on customer loyalty and subjective well-being. The following paragraph showed some previous studies suggesting the effect of satisfaction on subjective well-being and loyalty. Su, Swanson, and Chen (2016) in their study toward China upscale hotels found that upscale hotel visitor's satisfaction significantly affects individual subjective well-being. Similar to this study, Chen, Fu, \& Lehto (2016) explained that tourist's satisfaction with China's travel agency will affect their subjective wellbeing prior to influencing loyalty. The effect of satisfaction on subjective well-being was also found by Wu, Shen, Wang, Hou, and Yang (2019) in the study about heritage tourism in China. Similar to its effect on subjective well-being, satisfaction has been widely accepted as the robust determinant of loyalty. Huang et al. (2019) contended that the satisfaction of spa visitors would affect their loyalty. Similar to this study, Hapsari et al. (2017) explained the importance of satisfaction in creating airline passenger customer loyalty. These studies suggested that the higher the customer satisfaction is, the higher the loyalty will be. Since this study proposed the importance of spectator experience quality in creating customer satisfaction (Chen \& Chen, 2010; Jin et al., 2015) and customer satisfaction is the predictor of loyalty (Ali et al., 2018; Park, Hwang, Lee, \& Heo, 2018; D. Wu et al., 2019), there is a possibility that spectator experiential quality would indirectly affect spectator loyalty through spectator satisfaction. Thus:

H8 : Spectator satisfaction has a significant positive effect on subjective well-being.

H9 : Spectator satisfaction has a significant positive effect on spectator loyalty.

H10 : Spectator satisfaction mediates the effect of spectator experiential quality on Spectator loyalty.

\subsection{Subjective Well-Being}

Subjective well-being is about individuals' perception of their happiness and quality of life. Previous studies showed that an individual's subjective well-being has a significant positive effect on customer loyalty. For example, the study of Majid and Sadiq (2017) found the significant positive effect of shopping well-being on mall loyalty. Similar to this study the positive significant effect individual subjective well-being on customer loyalty was also found in the context of Chinese accommodation (Su et al., 2016). Smith and Puczko (2008) suggested that subjective well-being might be developed through relaxation of mind and body. Previous studies suggested that having a good experience toward interaction with a particular service provider will create subjective well-being. The study of Hussein (2018) suggested that the more positive an experience is perceived by shoppers, the higher the subjective well-being will be. As the quality of experience perceived by individuals affect subjective well-being and it is widely recognized that subjective well-being is the predictor of customer loyalty, it is predicted that subjective well-being will mediate the effect of experience quality on loyalty. Thus, the following hypotheses are proposed: 
H11 : Subjective well-being has a significant positive effect on spectator loyalty.

H12 : Subjective well-being mediates the effect of spectator experiential quality on spectator loyalty.

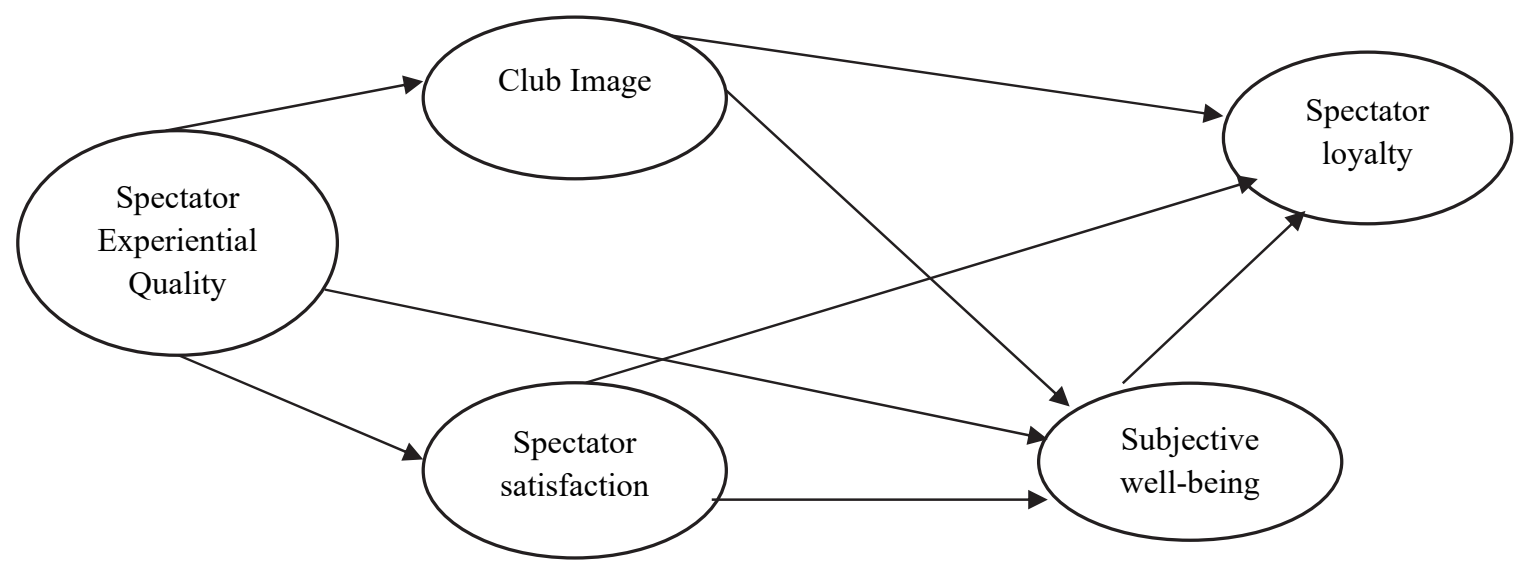

Fig. 1. Conceptual Model

\section{Research method}

A self-administered questionnaire survey was conducted to collect the data. A total of 250 respondents recruited during professional soccer matches in East-Java Province participated in this study. The survey was conducted during the Indonesian Soccer League (ISL) season of 2019. For this study, the convenience sampling method was employed. The data collected from these 250 samples are considered enough for the minimum required sample size for Partial Least Squares (PLS) analysis as Hair, Hult, Ringle, and Sarstedt (2014) suggested that the minimum sample for PLS is at least ten times the number of predictors from the largest number of antecedent constructs leading to a particular construct. Referring to this cut-off point, the minimum sample size required for this study is 40 (in this study, spectator loyalty is affected by four other constructs, hence the minimum sample size is $4 \times 10=40$ ). In order to ensure the logic of questionnaires, before collecting the data, the questionnaires were discussed with two academicians and two sports professionals. Validity and reliability checks were also conducted, and the results indicated that the questionnaires used are valid and reliable. As the measurement indicators used in this study were adapted from English literature, the process of translation and back translation were employed to make sure the meaning of questionnaires was still the same. For this study, the questionnaires were divided into two sections. The first section measured the demography of respondents, and the second section measures the variables used. The measures of spectator experiential quality and spectator satisfaction were adapted from Clemes et al. (2011), club image was adapted from Biscaia et al. (2016), subjective well-being was adapted from Lyubomirsky and Lepper (1999), and spectator loyalty was adapted from Bauer et al. (2008). Five-point Likert scale anchored between strongly agree (5) and strongly disagree (1) was used. In this study, data were analysed by using Partial Least Squares (PLS) with smartPLS 3.2.9. In performing PLS, three steps analysis was performed. They are outer loading evaluation, inner model evaluation, and hypotheses test. Outer model evaluation was reflected by the score of convergent validity, discriminant validity, and uni-dimensionality. To be free from convergent validity problems, the score of outer loading must be above 0.3 , and AVE is larger than 0.5 . Discriminant validity was tested through the evaluation of heterotrait-monotrait (HTMT) value. The score of HTMT must be below 0.9 . A construct must be uni-dimension. To ensure that the construct is uni-dimension, the score of composite reliability must be larger than 0.7. Inner mode evaluation was measured through the score of $\mathrm{R}^{2}, \mathrm{Q}^{2}$, and Goodness of Fit Index (GoF) Index. Since the nature of PLS is a prediction, there is no specific cut-off value for $\mathrm{R}^{2}$. Hair et al. (2014) suggested that the higher the score of $\mathrm{R}^{2}$, the better the proposed model is. Predictive relevance $\left(\mathrm{Q}^{2}\right)$ is about the prediction power of the model. For this study, the score of $\mathrm{Q}^{2}$ must be larger than $\left(0<\mathrm{Q}^{2}\right)$ (Esposito Vinzi, Chin, Henseler, \& Wang, 2010). Hair et al. (2014) suggested that the value of coefficient determination is categorized into three classes: weak (0.19), moderate (0.33), and substantial (0.67). For the score of GoF, Daryanto, de Ruyter, and Wetzels (2009) suggested that GoF small =0.1, GoF medium $=0.25$, and GoF large $=0.36$.

\section{Results}

\subsection{Demography of Respondents}

Two hundred and fifty samples participated in this study. The following paragraph summarizes the profile of respondents. Among 250 samples, $80.8 \%$ are males, around $85 \%$ are aged between 18 and 37 years old, $85.2 \%$ have supported the team more than six years and around $32 \%$ have information from live match. Table 1 showing the profile of respondents. 


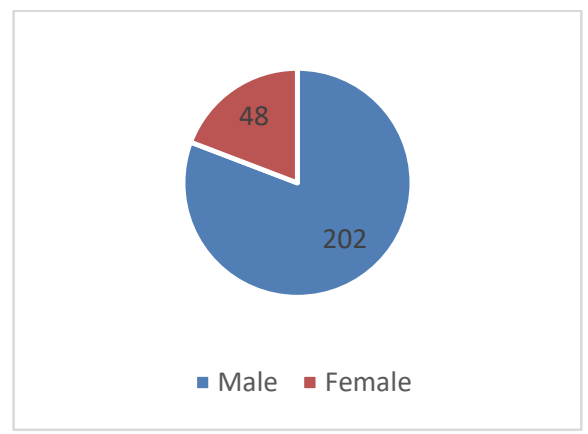

Gender

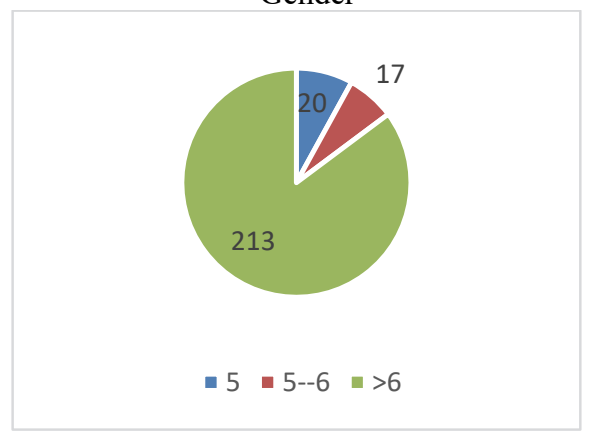

How Long being a Spectator

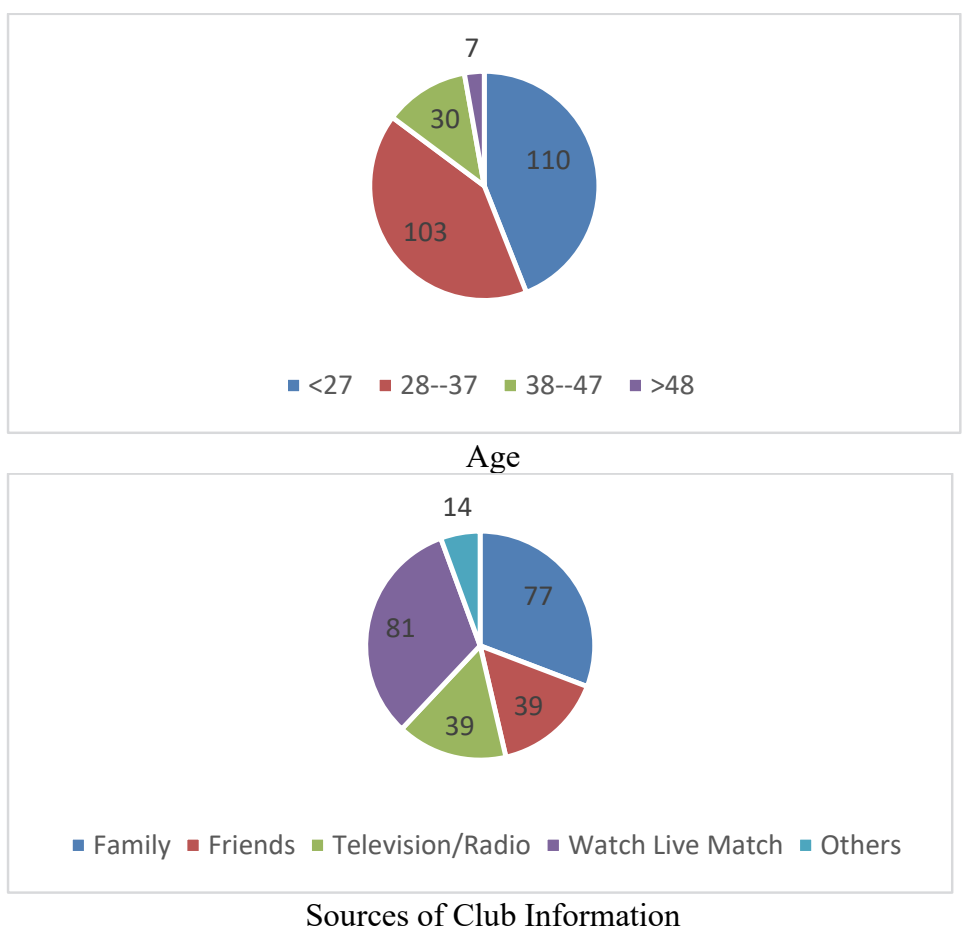

Fig. 2. Respondent Profiles

\subsection{Outer Model Evaluation}

To test the proposed hypotheses, the measures used must be free from validity and reliability problems. Convergent validity was evaluated through the score of outer loading and AVE. For this study, the score of outer loading for each indicator varied between 0.586 and 0.950 , with AVE for each construct has been larger than 0.5 . Thus, there is no convergent validity problem found. Discriminant validity was tested by using the HTMT score. In this study, the score of HTMT for each construct is less than 0.9 . For that reason, the measures used are free from the discriminant validity problem. To make sure that the construct is uni-dimension is necessary for PLS analysis (Esposito Vinzi et al., 2010). For this study, the uni-dimension analysis was performed through composite reliability. In order to be uni-dimension, a construct must have composite reliability more than 0.7. The composite reliability score in this study varied between 0.802 and 0.950 , which means all constructs are uni-dimension. Table 1 summarises the results of outer loading evaluation.

Table 1

Outer Loading Evaluation

\begin{tabular}{|c|c|c|c|c|c|c|c|c|}
\hline & Item & Outer Loading & AVE & Composite Reliability & CI & SEQ & SS & SWB \\
\hline \multirow[b]{5}{*}{ Club Image } & CI1 & 0,839 & \multirow{5}{*}{0,615} & & & & & \\
\hline & CI2 & 0,711 & & & & & & \\
\hline & $\mathrm{CI} 3$ & 0,829 & & & & & & \\
\hline & CI4 & 0,836 & & & & & & \\
\hline & CI5 & 0,693 & & 0,888 & & & & \\
\hline \multirow[b]{4}{*}{ Spectator Experience Quality } & SEQ1 & 0,803 & \multirow{4}{*}{0,508} & & & & & \\
\hline & SEQ2 & 0,652 & & & & & & \\
\hline & SEQ3 & 0,786 & & & & & & \\
\hline & SEQ4 & 0,586 & & 0,802 & 0.704 & & & \\
\hline \multirow[b]{3}{*}{ Spectator Satisfaction } & SS1 & 0,851 & \multirow{3}{*}{0,691} & & & & & \\
\hline & SS2 & 0,845 & & & & & & \\
\hline & SS3 & 0,797 & & 0,870 & 0.739 & 0.830 & & \\
\hline \multirow[b]{3}{*}{ Subjective Well-being } & SWB1 & 0,897 & \multirow{3}{*}{0,864} & & & & & \\
\hline & SWB2 & 0,941 & & & & & & \\
\hline & SWB3 & 0,950 & & 0,950 & 0.483 & 0.786 & 0.801 & \\
\hline \multirow[b]{3}{*}{ Spectator Loyalty } & SL1 & 0,836 & \multirow{3}{*}{0,730} & & & & & \\
\hline & SL2 & 0,867 & & & & & & \\
\hline & SL3 & 0,860 & & 0,890 & 0.610 & 0.617 & 0.804 & 0.797 \\
\hline
\end{tabular}


The inner model or structural model evaluation was evaluated through the score of coefficient determination $\left(\mathrm{R}^{2}\right)$, predictive relevance $\left(\mathrm{Q}^{2}\right)$, and Goodness of Fit $(\mathrm{GoF})$ Index. The statistical analysis indicated that the score of $\mathrm{R}^{2}$ varies between 0.294 and 0.563 . Following the rule of thumbs, the score of coefficient determinations is about moderate. Apart from the score of the coefficient of determination, the inner model evaluation was also reflected by the score of predictive relevance. Esposito Vinzi et al. (2010) suggested that to have predictive relevance, the score of $Q^{2}$ must be larger than 0 . In this study, the score of predictive relevance between 0.219 and 0.627 . The last indicator for inner model evaluation is GoF Index. The GoF calculation is 0.433 , referring to the cut-off value, the GoF index is considered large. Based on the inner model evaluation, the structural model proposed is robust. Thus, hypotheses might be tested.

Table 2

Inner Model Evaluation

\begin{tabular}{lll}
\hline Construct & $\mathbf{R}^{\mathbf{2}}$ & $\mathbf{Q}^{\mathbf{2}}$ \\
\hline SEQ & & 0.219 \\
CI & 0.294 & 0.410 \\
SS & 0.418 & 0.366 \\
SWB & 0.563 & 0.627 \\
SL & 0.563 & 0.427 \\
\hline
\end{tabular}

$\mathrm{GoF}=\sqrt{\overline{A V E} \times} \overline{R^{2}}=0.459 \times 0.409=0.433$

SEQ: Spectator Experiential Quality; CI : Club Image; SS : Spectator Satisfaction; SWB: Subjective Well-Being; SL : Spectator Loyalty

\subsection{Hypothesis Testing}

Hypothesis 1 suggested the significant positive effect of sport experience quality on club loyalty. The statistical analysis showed that there is no direct positive significant effect of sport experience quality on club loyalty $(b=-0.078 ; t=1.147)$. It means Hypothesis 1 is not supported. While sports experience quality does not have a significant positive effect on club loyalty, the statistical test indicated the sport experience quality has a significant positive effect on spectator subjective wellbeing $(b=0.412 ; t=7.512)$. It means Hypothesis 2 is supported. Hypothesis 3 and 4 suggested the effect of sport experience quality on both club image and spectator satisfaction, respectively. The findings indicated that sport experience quality has positive significant effect to both club image $(b=0.546 ; t=9.617)$ and spectator satisfaction $(b=0.647 ; t=11.389)$. Hypothesis 3 and 4 are supported. The effect of club image on subjective well-being is proposed by Hypothesis 5 . The statistical analysis found that club image does not affect subjective well-being $(b=-0.025 ; t=0.441)$, which means Hypothesis 5 is not supported. While club image does not have a significant effect on subjective well-being, this study revealed the significant positive effect of club image on spectator loyalty $(b=0.202 ; t=3.359)$. It means Hypothesis 6 is supported. Apart from its direct effect, the statistical calculation found the mediating effect of club image in the relationship between sports experience quality and club loyalty $(b=0.111 ; t=3.038)$. Moreover, this mediating effect supporting Hypothesis 7.

Table 3

Hypotheses Tests

\begin{tabular}{|c|c|c|c|c|}
\hline Hypothesis & Path & Path Coefficient & t-statistic & Remarks \\
\hline H1 & SEQ $\rightarrow$ SL & -0.078 & 1.147 & Not Supported \\
\hline $\mathrm{H} 2$ & SEQ $\rightarrow$ SWB & 0.412 & 7.512 & Supported \\
\hline H3 & SEQ $\rightarrow$ CI & 0.546 & 9.617 & Supported \\
\hline $\mathrm{H} 4$ & $\mathrm{SEQ} \rightarrow \mathrm{SS}$ & 0.647 & 11.389 & Supported \\
\hline H5 & $\mathrm{CI} \rightarrow \mathrm{SWB}$ & -0.025 & 0.441 & Not Supported \\
\hline H6 & $\mathrm{CI} \rightarrow \mathrm{SL}$ & 0.202 & 3.359 & Supported \\
\hline $\mathrm{H} 7$ & $\mathrm{SEQ} \rightarrow \mathrm{CI} \rightarrow \mathrm{SL}$ & 0.111 & 3.038 & Supported \\
\hline H8 & $\mathrm{SS} \rightarrow \mathrm{SWB}$ & 0.426 & 6.247 & Supported \\
\hline H9 & $\mathrm{SS} \rightarrow \mathrm{SL}$ & 0.229 & 2.878 & Supported \\
\hline H10 & $\mathrm{SEQ} \rightarrow \mathrm{SS} \rightarrow \mathrm{SL}$ & 0.146 & 2.860 & Supported \\
\hline H11 & $\mathrm{SWB} \rightarrow \mathrm{SL}$ & 0.502 & 6.352 & Supported \\
\hline $\mathrm{H} 12$ & $\mathrm{SEQ} \rightarrow \mathrm{SWB} \rightarrow \mathrm{SL}$ & 0.205 & 5.325 & Supported \\
\hline
\end{tabular}

SEQ : Spectator Experiential Quality; CI : Club Image; SS : Spectator Satisfaction; SWB : Subjective Well-being; SL: Spectator Loyalty

Hypothesis 8 predicted the effect of spectator satisfaction on subjective well-being. The statistical analysis showed that spectator satisfaction has a significant positive effect on subjective well-being $(b=0.426 ; t=6.247)$, hence Hypothesis 8 is supported. The importance of spectator satisfaction is also found in Spectator loyalty. The statistical analysis indicated that spectator satisfaction positively affected club loyalty $(b=0.229 ; t=2.878)$. It means Hypothesis 9 is supported. As an important 
predictor of club loyalty, this study also found the importance of spectator satisfaction as the mediating variable in the relationship between sports experience quality and club loyalty $(b=0.146 ; t=2.860)$. It is supporting Hypothesis 10 .

Hypothesis 11 suggested the importance of subjective well-being in affecting spectator loyalty. The statistical estimation found this positive effect $(b=0.502 ; t=6.352)$. It supported Hypothesis 11. Apart from its significant effect on club loyalty, subjective well-being was also found mediated the effect of sport experience quality on club loyalty $(b=0.205 ; t=5.325)$ which means supported Hypothesis 12

\section{Discussion}

This study aims to scrutinize the relationship among spectator experience quality, club image, spectator satisfaction, subjective well-being, and spectator loyalty in a single comprehensive conceptual model within the domain of the Indonesian football league. In order to answer the research objective, this study developed 12 hypotheses. The proposed hypotheses test both direct and indirect relationships. The following section will discuss the results of this study. While previous studies have mentioned the importance of experience quality in generating customer loyalty, this study did not find a significant relationship between these constructs. This finding challenges the previous studies declared the importance of experience quality on customer loyalty (Hussein et al., 2018; Wu et al., 2014). Theoretically, this insignificant effect probably occurs because in affecting spectator loyalty, spectator experience quality must be mediated by mediating variables. Refer to SOR theory (Mehrabian \& Russell, 1974), the stimuli received by an individual would affect emotional arousal, which lastly generates a response. Although this study did not find the significant positive effect of spectator experience quality on spectator loyalty, this study suggested the importance of spectator experiential quality on subjective well-being. It strengthens the previous contention explaining the important role of experience quality in creating subjective well-being (Baloglu et al., 2019; Huang et al., 2019). Practically, it implies that the better experience received by the visitor is, the higher subjective well-being will be. Similar to its effect on subjective well-being, spectator experience quality plays an important role in affecting both club image and spectator satisfaction. The significant positive effect of spectator experience quality on club image supporting the idea that the positive image will be gained by the business organization if the customers get a superior experience during the interaction with the business organization (Hussein et al., 2018; Jin et al., 2015). Spectator experience quality was also found to have a significant positive effect on visitor satisfaction. It is supporting previous studies arguing the importance of experience quality on satisfaction (Chen \& Chen, 2010; Wu et al., 2014). It implies that the better quality of experience perceived is, the more satisfied the customer will be.

Many studies have recognized the importance of image, especially in the area of marketing studies (Andreassen \& Lindestad, 1998; Hussein, 2018b; Jun, 2016). However, this study did not find the effect of club image on spectator subjective wellbeing. This finding challenges the S-O-R Theory (Mehrabian \& Russell, 1974) suggested that a stimulus (club image) will create emotional arousal (subjective well-being). The insignificant effect of club image on spectator subjective well-being possibly happens because as emotional arousal, the increase of spectator subjective well-being is not caused by club image. While club image does not have a significant positive effect on subjective well-being this study revealed the importance of club image in creating spectator loyalty. This significant effect in accord to previous studies suggested the effect of image on loyalty (Hapsari et al., 2017; Hussein, 2018b; Najafi \& Alvandi, 2017). The significant positive effect of club image of spectator loyalty means that the more positive the club image is, the higher the spectator loyalty will be. As club image has been recognized as the determinant of spectator loyalty and it is the result of spectator experience quality, this study proves the mediating role of club image in the relationship between spectator experience quality and spectator loyalty. This mediating effect answered the reason for the non-significant direct effect of spectator experiential quality on spectator loyalty.

While this study did not find a significant effect of club image on spectator subjective well-being, spectator satisfaction has been found to have an essential effect on spectator subjective well-being. The effect of spectator satisfaction on subjective well-being strengthens previous studies found the role of satisfaction in creating individual well-being ( Chen et al., 2016; Su et al., 2016; Wu et al., 2019). This significant effect practically implies that sports club, especially football club can play an important role in creating individual well-being by satisfying the spectators. Similar to its effect on subjective well-being, spectator satisfaction was found to be an important predictor of spectator loyalty, as suggested by previous scholars (Hapsari et al., 2017; Keshavarz \& Jamshidi, 2018; Liu \& Jang, 2009). This finding means that the more satisfied the spectator with the supported club is, the higher their loyalty will be. The interesting finding related to spectator satisfaction is revealed by this study as this study indicated that spectator satisfaction mediated the effect of spectator experiential quality on spectator loyalty. This mediating effect suggested S-O-R Theory (Mehrabian \& Russell, 1974) exclaimed that a stimulus given to an individual would create emotional arousal that finally builds a response.

As the perception of individual perception of happiness, subjective well-being has been acknowledged as the determinant of loyalty, especially in the domain of tourism (Chen et al., 2016; Su et al., 2016). These articles exclaimed that the happiness of tourists gathered from their visit to a particular destination would lead to the revisit intention. Since this study found the significant positive effect of spectator subjective well-being on spectator loyalty, this study theoretically supported the previous studies suggesting the importance of subjective well-being on loyalty. Spectator subjective well-being does not only have a significant positive effect on spectator loyalty. This study revealed that spectator subjective well-being mediated the effect 
of spectator experiential quality on spectator loyalty. Since this study did not find the direct effect of spectator experiential quality of spectator loyalty, and this study suggested that subjective well-being fully mediates the effect of spectator experiential quality on spectator loyalty.

Upon the completion of the proposed research objectives, this study provides both theoretical and practical contributions. The first theoretical contribution is about the comprehensive conceptual model integrating the notion of spectator experiential quality, club image, spectator satisfaction, and subjective well-being in predicting soccer spectator loyalty in the context of the Indonesian sports industry. Second, this study contributes to the theoretical standpoint by supporting S-O-R theory (Mehrabian \& Russell, 1974) that experiential quality as a stimulus received by the spectator would not directly affect the individual response. Prior to affecting loyalty, the experiential quality will affect various intervening variables in which these intervening variables would create a response. The last theoretical contribution proposed by this study is about the mediating variables revealed by this study. Based on the mediation test analysis, this study found that club image, spectator satisfaction, and subjective well-being, apart from its significant effect on spectator loyalty, these variables also found mediated the effect of spectator experiential quality on spectator loyalty.

From a practical perspective, the findings of this study provide a comprehensive guideline for soccer club management as well as sports professionals to enhance spectator loyalty in supporting a soccer club. In addition, this study confirms that the quality of experience perceived by the spectators is indicated by three important factors name interaction quality, service quality, and physical quality. The last practical contribution is about the importance of club image in enhancing spectator loyalty. This finding means that the soccer club should build a high reputation to enhance supports from its fans.

\section{Limitation and future studies}

While providing some contributions to the body of sports marketing knowledge, this study also faced some limitations. The first limitation is the convenience sampling used in this study. As this study employed a convenience sampling method, the results of this study cannot be generalized to the other population. For that reason, future studies might replicate the conceptual model for other industrial settings. The second limitation is regarding the use of variable of sport experiential quality. Previous studies such as Lemke et al. (2011) and Hussein (2018) suggested that experience is a culture-based construct. The experiences expected by individuals will be varied among industries. Hence, future studies might explore the structure and dimension of sport experiential quality in other settings of culture.

\section{Acknowledgement}

The authors would like to thank the anonymous referees for their comments on earlier version of this paper.

\section{References}

Ali, F., Kim, W. G., Li, J., \& Jeon, H.-M. (2018). Make it delightful: Customers' experience, satisfaction and loyalty in Malaysian theme parks. Journal of Destination Marketing \& Management, 7, 1-11.

Andreassen, T. W., \& Lindestad, B. (1998). Customer loyalty and complex services: The impact of corporate image on quality, customer satisfaction and loyalty for customers with varying degrees of service expertise. International Journal of Service Industry Management, 9(1), 7-23.

Baloglu, S., Busser, J., \& Cain, L. (2019). Impact of experience on emotional well-being and loyalty. Journal of Hospitality Marketing \& Management, 28(4), 427-445.

Bauer, H. H., Stokburger-Sauer, N. E., \& Exler, S. (2008). Brand Image and Fan Loyalty in Professional Team Sport: A Refined Model and Empirical Assessment. Journal of Sport Management, 22(2), 205-226.

Biscaia, R., Ross, S., Yoshida, M., Correia, A., Rosado, A., \& Marôco, J. (2016). Investigating the role of fan club membership on perceptions of team brand equity in football. Sport Management Review, 19(2), 157-170.

Brady, M. K., \& Cronin, J. J. (2001). Customer orientation: Effects on customer service perceptions and outcome behaviors. Journal of Service Research, 3(3), 241-251.

Chen, C.-F., \& Chen, F.-S. (2010). Experience quality, perceived value, satisfaction and behavioral intentions for heritage tourists. Tourism Management, 31(1), 29-35.

Chen, Y., Fu, X., \& Lehto, X. Y. (2016). Chinese tourist vacation satisfaction and subjective well-being. Applied Research in Quality of Life, 11(1), 49-64.

Chun Ma, S., \& Kaplanidou, K. (2019). Service quality, perceived value and behavioral intentions among highly and lowly identified baseball consumers across nations. International Journal of Sports Marketing and Sponsorship, 21(1), 46-69.

Clemes, M. D., Brush, G. J., \& Collins, M. J. (2011). Analysing the professional sport experience: A hierarchical approach. Sport Management Review, 14(4), 370-388.

Daryanto, A., de Ruyter, K., \& Wetzels, M. (2009). Getting a discount or sharing the cost: The influence of regulatory fit on consumer response to service pricing schemes. Journal of Service Research, 13(2), 153-167.

Esposito Vinzi, V., Chin, W., Henseler, J., \& Wang, H. (Eds.). (2010). How to write up and report PLS analyses. In Handbook 
of Partial Least Squares. (p. 655). Hiedelberg: Springer Berlin Heidelberg.

Hair, J. F., Hult, G. T. M., Ringle, C. M., \& Sarstedt, M. (2014). A primer of partial least squares structural equation modelling (PLS-SEM). Thousnd Oaks: SAGE Publications.

Hapsari, R., Clemes, M., \& Dean, D. (2017). The impact of service quality, customer engagement and selected marketing constructs on airline passenger loyalty. International Journal of Quality and Service Sciences, 9(1), 21-40.

Hapsari, R., Hussein, A. S., \& Handrito, R. P. (2020). Being fair to customers: A strategy in enhancing customer engagement and loyalty in the Indonesia Mobile Telecommunication Industry. Services Marketing Quarterly, 41(1), 49-67.

Huang, Y.-C., Chen, C.-C. B., \& Gao, M. J. (2019). Customer experience, well-being, and loyalty in the spa hotel context: integrating the top-down \& bottom-up theories of well-being. Journal of Travel \& Tourism Marketing, 36(5), 595-611.

Hussein, A. S. (2018a). Shopping Experience and Subjective Well-being. Journal of Indonesian Economy and Business, 33(3).

Hussein, A. S. (2018b). Revisiting the importance of casual dining experience quality: an empirical study. International Journal of Quality and Service Sciences, 10(3), 233-252.

Hussein, A. S., Hapsari, R. D. V., \& Yulianti, I. (2018). Experience quality and hotel boutique customer loyalty: Mediating role of hotel image and perceived value. Journal of Quality Assurance in Hospitality \& Tourism, 19(4), 442-459.

Jin, N. (Paul), Lee, S., \& Lee, H. (2015). The Effect of Experience Quality on Perceived Value, Satisfaction, Image and Behavioral Intention of Water Park Patrons: New versus Repeat Visitors. International Journal of Tourism Research, $17(1), 82-95$.

Jun, K. S. (2016). The structural relationships of destination image, awareness, uniqueness and destination loyalty in periurban ecotourism destination. European Journal of Tourism, Hospitality and Recreation, 7(3).

Kandampully, J., \& Suhartanto, D. (2000). Customer loyalty in the hotel industry: the role of customer satisfaction and image. International Journal of Contemporary Hospitality Management, 12(6), 346-351.

Keshavarz, Y., \& Jamshidi, D. (2018). Service quality evaluation and the mediating role of perceived value and customer satisfaction in customer loyalty. International Journal of Tourism Cities, 4(2), 220-244.

Kotler, P., \& Keller, K. L. (2012). Marketing Management. New Jersey: Pearson Education.

Lemke, F., Clark, M., \& Wilson, H. (2011). Customer experience quality: an exploration in business and consumer contexts using repertory grid technique. Journal of the Academy of Marketing Science, 39(6), 846-869.

Liat, C. B., Chuan, G. C., C., I. B., \& Shaheen, M. (2019). Service recovery, customer satisfaction and customer loyalty: evidence from Malaysia's hotel industry. International Journal of Quality and Service Sciences, 11(2), 187-203.

Liu, Y., \& Jang, S. S. (2009). Perceptions of Chinese restaurants in the US: what affects customer satisfaction and behavioral intentions? International Journal of Hospitality Management, 28(3), 338-348.

Lyubomirsky, S., \& Lepper, H. S. (1999). A Measure of Subjective Happiness: Preliminary Reliability and Construct Validation. Social Indicators Research, 46(2), 137-155.

Majid, M. S., \& Sadiq, E.-H. S. M. (2017). Mall image, shopping well-being and mall loyalty. International Journal of Retail \&amp; Distribution Management, 45(10), 1114-1134.

Mehrabian, A., \& Russell, J. A. (1974). An approach to environmental psychology. the MIT Press.

Najafi, S., \& Alvandi, M. (2017). The impacts of self-concept on brand image and loyalty with mediating role of the consumers' need for uniqueness theory. International Journal of Business Innovation and Research, 13(4), 519-537.

Park, S., Hwang, D., Lee, W. S., \& Heo, J. (2018). Influence of nostalgia on authenticity, satisfaction, and revisit intention: The case of Jidong mural alley in Korea. International Journal of Hospitality \& Tourism Administration, 1-17.

Rather, R. A. (2020). Customer experience and engagement in tourism destinations: the experiential marketing perspective. Journal of Travel \& Tourism Marketing, 37(1), 15-32.

Shafiee, M. M., \& Es-Haghi, S. M. S. (2017). Mall image, shopping well-being and mall loyalty. International Journal of Retail \& Distribution Management, 45(10).

Smith, M., \& Puczko, L. (2008). Health and wellness tourism. Routledge.

$\mathrm{Su}, \mathrm{L}$., Swanson, S. R., \& Chen, X. (2016). The effects of perceived service quality on repurchase intentions and subjective well-being of Chinese tourists: The mediating role of relationship quality. Tourism Management, 52, 82-95.

Vargo, S. L., \& Lusch, R. F. (2010). A service dominant logic for marketing. In M. Maclaran, B. Saren, S. M, \& Tadajewski (Eds.), The Sage Handbook of Marketing Theory. London: SAGE Publication ltd.

Wu, D., Shen, C., Wang, E., Hou, Y., \& Yang, J. (2019). Impact of the perceived authenticity of heritage sites on subjective well-being: A study of the mediating role of place attachment and satisfaction. Sustainability, 11.

Wu, H.-C., Cheng, C.-C., \& Ai, C.-H. (2018). A study of experiential quality, experiential value, trust, corporate reputation, experiential satisfaction and behavioral intentions for cruise tourists: The case of Hong Kong. Tourism Management, 66, 200-220.

Wu, H.-C., Wong, J. W.-C., \& Cheng, C.-C. (2014). An Empirical Study of Behavioral Intentions in the Food Festival: The Case of Macau. Asia Pacific Journal of Tourism Research, 19(11), 1278-1305. 
(C) 2020 by the authors; licensee Growing Science, Canada. This is an open access article distributed under the terms and conditions of the Creative Commons Attribution (CC-BY) license (http://creativecommons.org/licenses/by/4.0/). 